\title{
Characterization of climate and crop productivity using DSSAT for SW Uttarakhand, India
}

\author{
S. K. Tripathi, G. Pranuthi, S. Dubey, G. V. Kumar \\ \& L. Mfwango \\ Department of Water Resources Development and Management, \\ Indian Institute of Technology, India
}

\begin{abstract}
Haridwar district in south west Uttarakhand India is agriculturally very sensitive as this contributes about $35 \%$ food grain and $80 \%$ sugar to the total production of the state. Weather conditions affected production both directly and indirectly. DSSAT is a very useful tool presently available for yield forecasting taking into account the weather condition, soil condition, crop management condition and genetic coefficients. Weather data (1979-2011) was collected from the Indian Institute of Technology, Roorkee whereas the data of soil, crop management and genetic coefficients were collected conducting survey from different parts of the district. Acreage and yield data of rice, wheat and sugarcane of the district was obtained from the office of the Director Agriculture Uttarakhand for the period 2000-2011. Weather data analyzed using DSSAT recorded $1026 \mathrm{~mm} /$ year average annual rain with 68 rainy days/year and $65 \%$ probability of wetness/year in Haridwar. Actual average yield of rice, wheat and sugarcane was reported as $22.4 \mathrm{q} / \mathrm{ha}, 25.0 \mathrm{q} / \mathrm{ha}$ and $609 \mathrm{q} / \mathrm{ha}$ respectively. The DSSAT however forecasted the average yield of rice and wheat as $26.3 \mathrm{q} / \mathrm{ha}$ and $28.2 \mathrm{q} / \mathrm{ha}$ respectively. Marginally higher forecast of yield in rice and wheat over the actual through DSSAT needs further scrutiny. Regression model however responded at par with the actual forecasting the average yield in rice as $22.9 \mathrm{q} / \mathrm{ha}$, wheat as $25.2 \mathrm{q} / \mathrm{ha}$ and sugarcane as $610 \mathrm{q} / \mathrm{h}$. These observations confirm the scope of using DSSAT in characterising weather condition and crop yield forecasting in Uttarakhand.

Keywords: bhabhar, khadar, DSSAT, rabi, kharif.
\end{abstract}




\section{Introduction}

Haridwar located in the south western part of Uttarakhand India is agriculturally a very sensitive district contributing about 35\% food grain and $80 \%$ sugar production to the total production of the state. Geographical area of Haridwar is $2360 \mathrm{~km}^{2}$ and falls in the sub humid agro climate zone. Ganges is a perennial stream originating in Himalaya flows through Haridwar. A large number of seasonal streams originate from shiwalik ranges present in the northern part of the district and flow over land to join Ganges. The district is rich in surface (5.6 $\left.\mathrm{km}^{3}\right)$ and ground water $\left(0.9 \mathrm{~km}^{3}\right)$ resources both [1]. There are three land zones present in the district called bhabhar in north, khaddar in south and normal in centre. Artesian wells use to be active during rainy season in the past in khaddar zone. A very good canal network exists in this district. Their irrigated cropping intensity is $>200 \%$ and the cropping pattern is primarily consists of rice, wheat and sugarcane [1]. The yearly variation in the climatic condition unlike in any other part of the country is natural and affected cropping pattern and crop productivity [2-4]. The average weather condition viz., temperature, humidity and sunshine etc influenced rainfall and vice versa [2].

DSSAT is a very good tool for decision making in crop management and yield forecasting and characterising the weather and soil conditions [5]. There is selective statistical software available to analyze weather data particularly the rainfall but they are limited to general characterization. The DSSAT specifically focussed on the statistical analysis weather data from crop planning and management point of view. However no report on rainfall characterization using DSSAT is available for region.

Keeping these points in view the study was undertaken with the objectives to use DSSAT as a tool to characterise weather and crop productivity of Haridwar district in Uttarakhand India.

\section{Study area}

Haridwar is an important district of South West Uttarakahnd extending from $77^{\circ}$

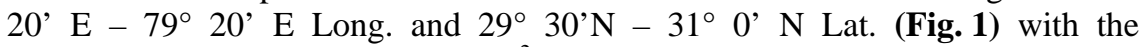
geographical area of about $2360 \mathrm{~km}^{2}$. From the agriculture point of view this is an important district of Uttarakhand. This consists of three sub divisions viz. Roorkee, Bhagwanpur, Laksar and six development blocks viz. Roorkee, Bhagwanpur, Laksar, Khanpur, Bahdarabad and Narsan. There are 622 villages.

Haridwar experiences humid and sub humid agro climate with three distinct crop seasons. The summer season is called zaid (April-May), rainy season is called kharif (June-September) and winter season is called rabi (OctoberMarch). The average annual rainfall of the district is $1074 \mathrm{~mm}$ and distribution is variable recording high in northern part and low in southern part. Annual rainfall received is $84 \%$ during kharif and $16 \%$ during rabi and zaid seasons. Topography in the district is also variable. Shiwalik range $(869 \mathrm{~m})$ is present in the north and plain $(232 \mathrm{~m})$ land in south. Ganges is the main, and perennial 


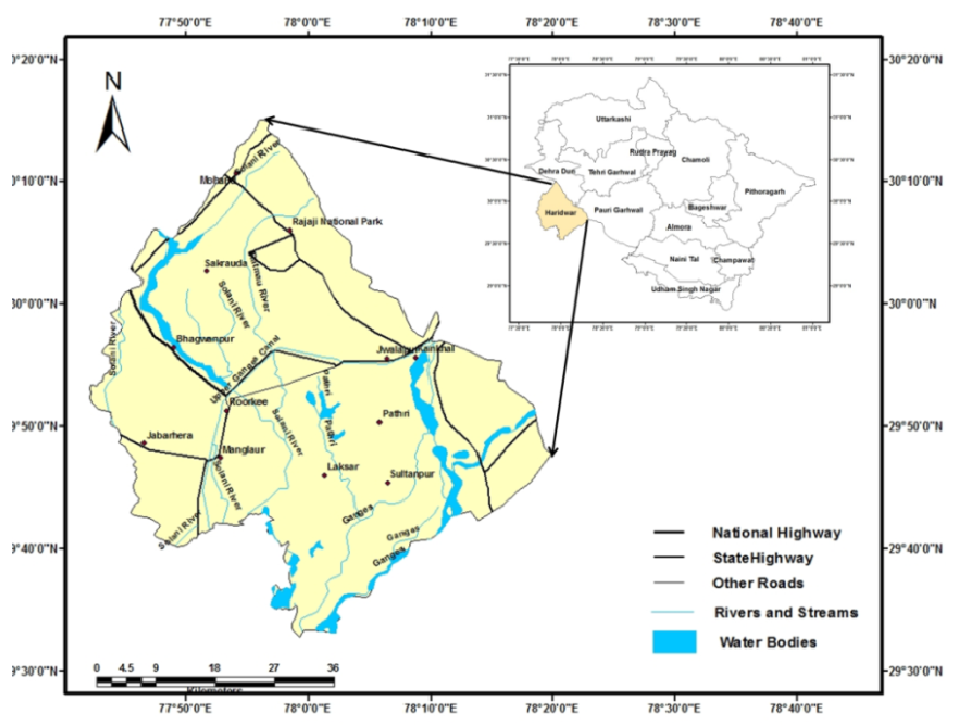

Figure 1: $\quad$ Map of Haridwar (Uttarakhand).

stream flowing through the district. Seasonal streams called Solani, Ratmau, Ranipur, and Pathari originating from Shivalik ranges join holy river Ganges.

Livelihood of the majority of rural population is agriculture. Farmers are very progressive. Major crops occupying the net sown area of the district are rice (15\%), wheat (36\%) and sugarcane (58\%). Crops are irrigated with average productivity of $2.2 \mathrm{t} / \mathrm{ha}, 2.5 \mathrm{t} / \mathrm{ha}$ and $61 \mathrm{t} / \mathrm{ha}$ in rice, wheat and sugarcane respectively [1]. About $98 \%$ of the cultivated area is irrigated through a network of canals of Uppar Ganga Canal System whereas about 2\% is irrigated by tube well. The surface and ground water utilized in the district is $2.3 \mathrm{~km}^{3}$ and $0.8 \mathrm{~km}^{3}$ respectively [1].

There are three distinct soil zones called bhabhar, khaddar and normal lands [6-8] in the district.

In the vicinity of Shivalik Hills, the gradient is steep and soils present there are called bhabhar or Entisols occupy about 5\% of the geographical area of the district. They are shallow to deep sandy soils underlain with boulders. They are poor in water holding capacity and fertility.

The flood plain zone of the district is called the khaddar/Tarai or Mollisols. This occupies about $15 \%$ of the geographical area in the district. Soil is fertile and rich in clay and organic matter. These are one of the most productive soils in the country.

The plain areas bearing all the good conditions for cultivation of crops with well developed soil profile are normal lands and also called Ultisols. This is distributed throughout the district and occupies about $80 \%$ of the geographical area. Soils are brown in colour. The soil horizon is fully developed. 
There are three sugar mills located at village Ikbalpur, Laksar and Libberhedy with annual sugarcane crushing capacity of about 7.0 million tonnes per year are present in the district.

\section{Methodology}

Daily weather data (rainfall, maximum temperature, minimum temperature and sunshine hours) for the period 1979-2011 recorded at the agro meteorological observatory of the Department of Water Resources Development and Management, Indian Institute of Technology Roorkee, India was collected. Annual variability of rainfall was statistically analyzed using Fourier method on Microsoft excels.

Acreage and production of rice, wheat and sugarcane was collected from the office of the Director Agriculture Uttarakhand and District Agriculture Officer Haridwar [7, 8] and is presented in Table 2.

The DSSAT $v 4.5$ is a collection of number of crop models that operate together to give a functional output. This is supported by data base files created for soil (S built), weather (weatherman), crop management/experimental data (X built) and genotype (genotype coefficient). Soil samples were collected from all over the district. Climate file was created running weatherman to obtain the average values of solar radiation $\left(\mathrm{MJ} / \mathrm{m}^{2} /\right.$ day), maximum temperature $\left({ }^{\circ} \mathrm{C}\right)$, minimum temperature $\left({ }^{\circ} \mathrm{C}\right)$, rainfall $(\mathrm{mm})$ and rainy days (days), mean maximum temperature of dry days TxMND), standard deviation of maximum temperature of dry days (TxSDD), mean maximum temperature of wet days (TxMNW), standard deviation of maximum temperature of wet days (TxSDW), mean minimum temperature of dry days TxMND), standard deviation of minimum temperature of dry days (TxSDD), mean minimum temperature of wet days (TxMNW), standard deviation of minimum temperature of wet days (TxSDW), Kurtosis (Ku), mean maximum solar radiation of dry days (XMND), standard deviation of solar radiation of dry days (XSDD), mean minimum solar radiation of wet days (XMNW), standard deviation of solar radiation of wet days (XSDW), probability of dry dry wet sequence (PDDW), probability of wet dry wet sequence (PWDW), probability of wet wet sequence (PWW) and probability of wet day (PW). DSSAT was run to simulate productivity of rice and wheat in Haridwar district for the period 2000-2011[9, 10].

The regression model was another statistical tool applied to simulate productivity scenario of Haridwar district from 2000-2011 [11, 12]. Average annual yield along with the weekly average temperature, humidity and rainfall was taken for the crop growing period to run the model. Regression model is explained using following equation:

$$
Y=a_{0}+\sum_{i=1}^{p} \text { ai } \cdot \mathrm{Zi}+\sum_{\mathrm{i} \neq \mathrm{j}}^{\mathrm{p}} \text { aij } \cdot \mathrm{Zij}+\mathrm{e}
$$

where,

$$
\begin{aligned}
\mathrm{Zi} & =\mathrm{a}_{0}+\sum_{\mathrm{w}=1}^{\mathrm{m}} \text { riw.Xiw } \\
\mathrm{Zij} & =\sum_{\mathrm{w}=1}^{\mathrm{m}} \text { rijw. Xiw.Xjw }
\end{aligned}
$$


where,

$\mathrm{Y} \quad=$ crop yield and

e $\quad=$ random error

$\mathrm{r}_{\mathrm{iw}} / \mathrm{r}_{\mathrm{ijw}}=$ correlation coefficient of $\mathrm{Y}$ with $\mathrm{i}^{\text {th }}$ weather variable/ product of $\mathrm{i}^{\text {th }}$ and $\mathrm{j}^{\text {th }}$ weather variables in $\mathrm{w}^{\text {th }}$ week

$\mathrm{m}=$ week of forecast

$\mathrm{p} \quad=$ number of weather variables

$\mathrm{Zi}$ and $\mathrm{Zij}=$ independent variables which are functions of the basic weather variables like maximum and minimum temperature, rainfall, relative humidity etc.

Yields of rice, wheat and sugarcane for the period 2000-11 were simulated using regression models.

\section{Results and discussion}

Observations recorded on climate variability and crop productivity using DSSAT is presented and discussed in the forthcoming paragraphs.

\subsection{Climate}

A climate file with monthly average generated using DSSAT v 4.5 models with daily weather data of solar radiation, maximum temperature, minimum temperature, rainfall and rainy days from Jan. 01, 1979 to Dec. 31, 2011 is presented in Table 1 . The average annual mean probability of dry/dry/wet sequence was recorded as 0.12; this is highest during August (0.33) and lowest during November (0.02). The average annual mean probability of wet/dry/wet sequence was recorded as 0.22; this is highest during August (0.4) and lowest during March (0.09). The average annual mean probability of wet/wet sequence was recorded as 0.47; this was highest during August (0.62) and lowest during November (0.35). The average annual mean probability of only wet sequence was recorded as 0.18; this was highest during August (0.49) and lowest during November (0.04). The month of August in Haridwar is critical for Kharif season crops as they are at grand growth and flowering stage. Observations recorded confirm that the probability of wet days during August is very high therefore rain fed kharif season crops are safe. The crop productivity is stable during kharif season but unstable during rabi season has also already been reported for Haridwar [6-8].

Maximum and minimum temperature as well as the solar radiation for dry days and wet days in the month, a valuable information to assess crop health when this is not constrained by water and nutrient, has been generated through DSSAT. This information is extremely important from point of view of forecasting insect pest and disease. Since no record of yield loss caused to different crops in the wake of insect pest and disease incidence no relationship could be analyzed in this study.

The actual and fourier analyzed (at 50\% probability) values of annual rainfall are presented in Fig. 2. Actual extreme events of rainfall occurring at the interval of $8 \pm 2$ years recorded increase at about $20 \mathrm{~mm} /$ year in the Haridwar district. 
Similar pattern of event was also expressed in fourier analysis. In 1980, 1988, 2000 and 2010 Extreme rainfall events recorded were $1100 \mathrm{~mm}, 1400 \mathrm{~mm}$, $1500 \mathrm{~mm}$ and $1600 \mathrm{~mm}$ during 1980, 1988, 2000 and 2010 respectively. This observation shows that the next extreme rainfall event that is likely to occur by 2018 in Haridwar district will be still fierce.

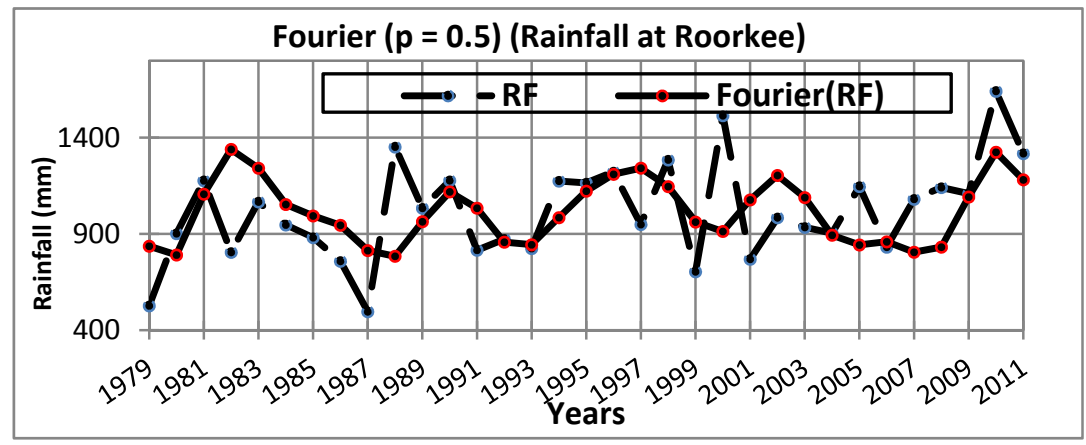

Figure 2: Annual rainfall pattern.

\subsection{Crop productivity}

Rice, wheat and sugarcane are the predominating crops occupying about 95\% of net sown area in the district of Haridwar. Area and productivity of these crops given in Table 2 revealed that area under rice is drastically decreasing at about $800 \mathrm{ha} /$ year whereas the area under sugarcane is increasing at about 500 ha/year. Surprisingly the wheat area remains unchanged. Decrease in the area of rice could be ascribed to the shortage of agricultural labour needed to work in the rice field during transplanting, weeding and harvesting. Increase in the sugarcane area could be attributed to the decrease rice acreage. The presence of three sugar mills in the district also act as a driving force for increasing sugarcane acreage $[5,6]$. Wheat is a staple food crop but rice and sugarcane are treated as the cash crops in the area. Farmers also evaluate the relative benefit between rice and sugarcane and then decide their cropping pattern. Wheat is also grown as an intercrop of sugarcane therefore there is no loss of its acreage. The year to year productivity variation in rice and wheat is not remarkable that may be attributed to its richness in surface and ground water [7].

It is surprising to note that productivity of sugarcane in the area is gradually increasing probably due to the increased technical and infrastructural support from sugar mills. Cultivation of sugarcane is although distributed throughout the district but is more concentrated in khadar zone due to the soil fertility and easy water availability. It is common observation of farmers that the productivity of sugarcane, rice and wheat is increased when rainfall is less than average. Heavy rainfall adversely affected their crop for want of surface drainage facility in the area. 


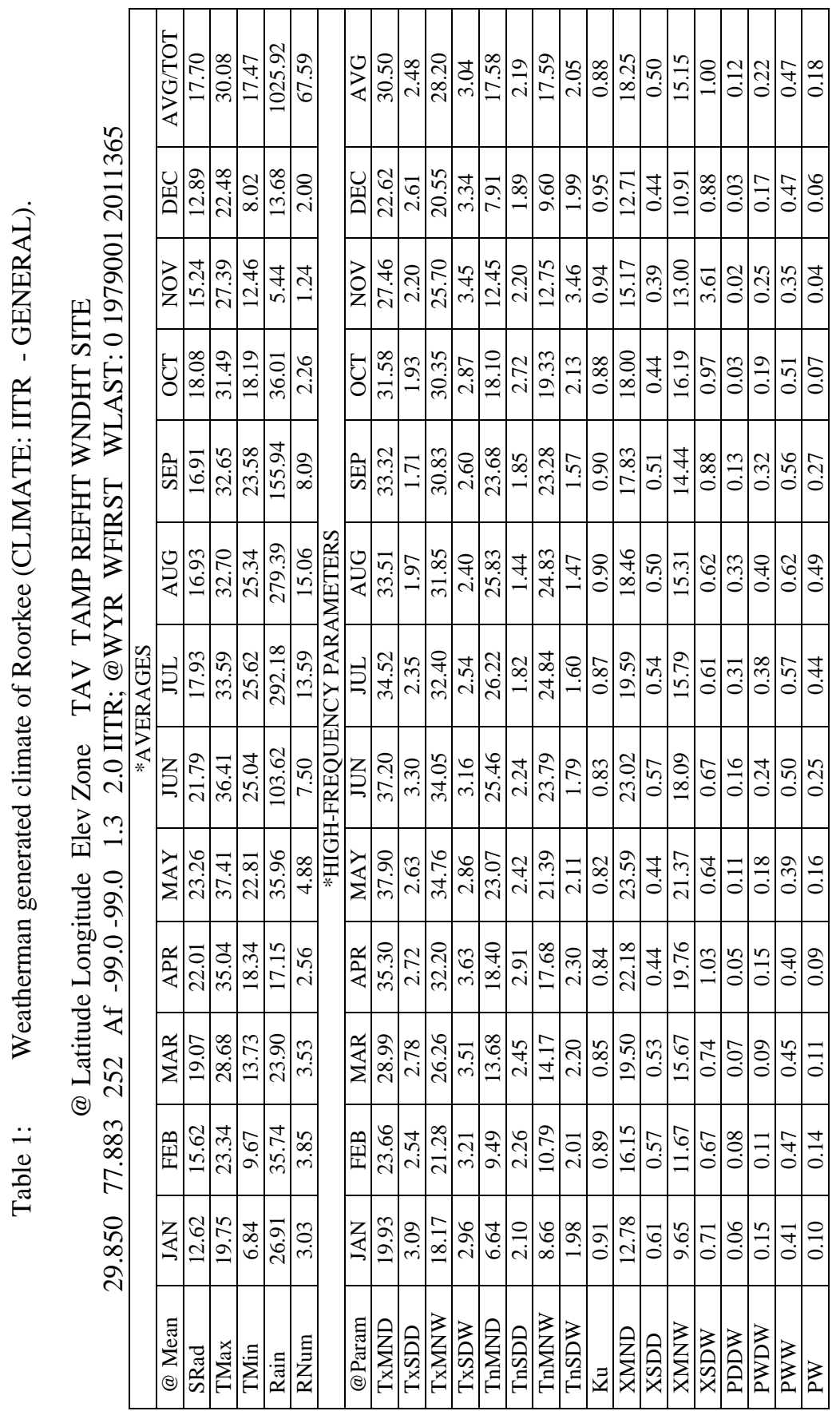




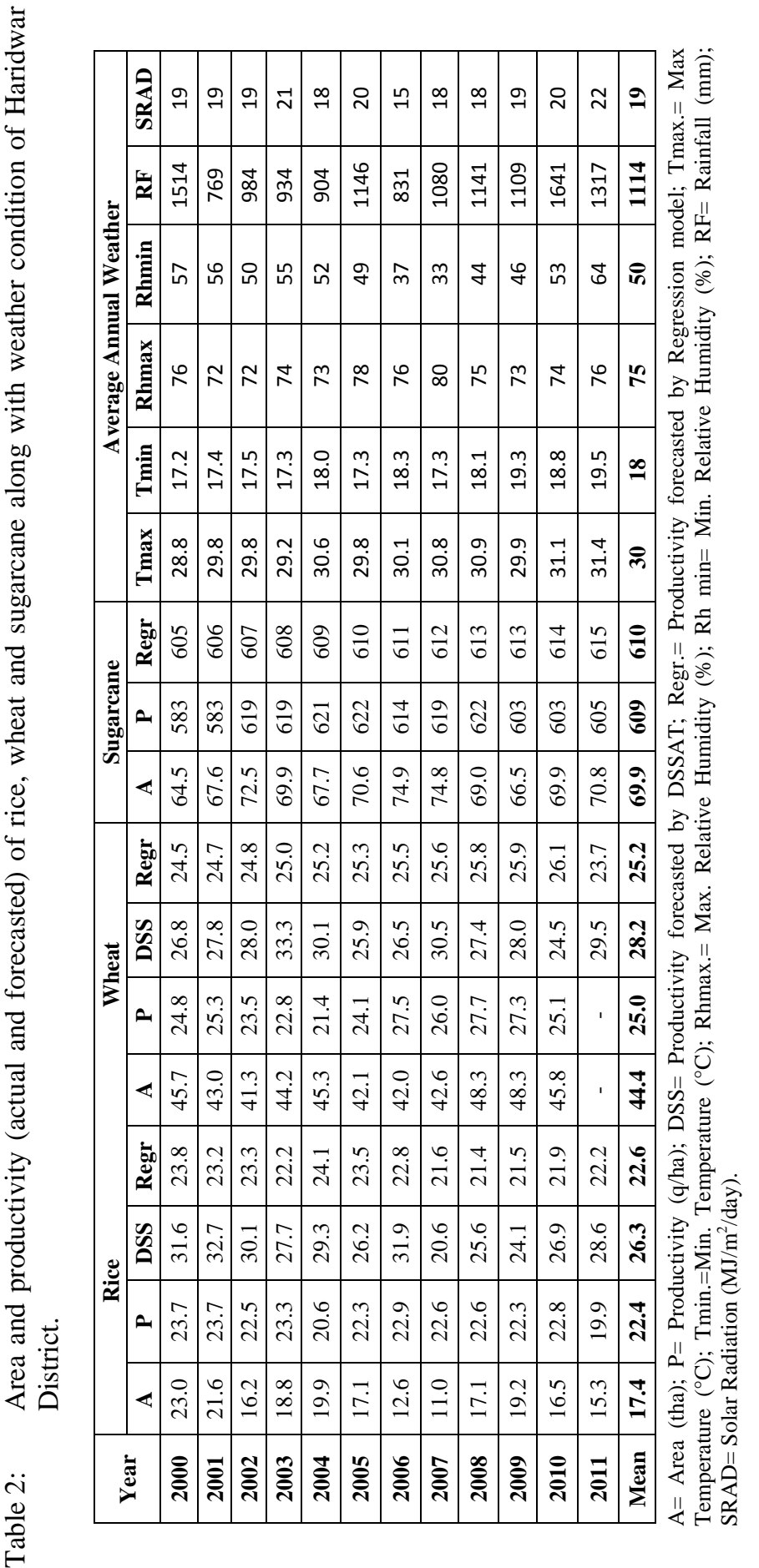

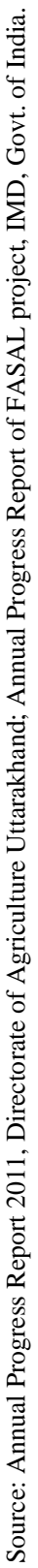




\subsection{Model analysis}

Yield recorded (actual) and simulated by DSSAT and regression models from 2000-2011 is presented in Table 2. The DSSAT forecasted productivity was high (26.3 q/ha in rice and $28.2 \mathrm{q} / \mathrm{ha}$ in wheat) over that of the actual (22.4 q/ha in rice and $25.0 \mathrm{q} / \mathrm{ha}$ in wheat). The actual average yield of sugarcane was 609 q/ha. This could not be simulated using DSSAT. Gap between actual and DSSAT model predicted could be minimized by improving the collection of crop management data.

The regression model forecasted yield (22.6 q/ha in rice and $25.2 \mathrm{q} / \mathrm{ha}$ in wheat and $610 \mathrm{q} / \mathrm{ha}$ in sugarcane) very close to the actual (22.4 q/ha in rice and $25.0 \mathrm{q} / \mathrm{ha}$ in wheat and $609 \mathrm{q} / \mathrm{ha}$ ). The regression model has taken only weather condition into account ignoring the crop management practice, genetic character and soil conditions. The regression model has been reported to be very helpful to find out the relationship between different weather elements and crop productivity $[9,11,12]$. Weather elements that significantly affected the crop productivity was rainfall and humidity in rice; minimum temperature in wheat whereas maximum temperature and solar radiation in sugarcane in the district of Haridwar.

\section{Conclusion}

The study undertaken could be concluded with the facts that DSSAT is a useful tool for weather data analysis and yield forecasting of rice, wheat and sugarcane. The information on different probabilities of wet days calculated by DSSAT could be used for crop planning and management. Marginally higher forecast of yield by DSSAT could be acceptable at this stage and further improvements on soil water balance model could be incorporated and or field data collection could be further refined. The potential factors that affected yield were: humidity and rainfall in rice; minimum temperature in wheat whereas the maximum temperature and solar radiation in sugarcane were analysed through regression model.

\section{References}

[1] Anonymous, Agricultural Statistics of Uttarakhand. Published by Directorate of Agriculture Uttarakhand Dehradun India. pp. 280, 2011.

[2] Tripathi S.K., Manvendra Singh and Ashish Pandey, Agroclimatic Variability Analysis of Roorkee, Uttarakhand. J. of IWRS 27 (3 and 4): pp. 24-30.2007.

[3] Tripathi S.K., Manvendra Singh and Ashish Pandey, Climate change at Roorkee (Uttarakhand): a case study J. IWRS 28 (1): pp. 19-2, 2008.

[4] Tripathi S.K., Manvendra Singh and Ashish Pandey, Analysis of Agroclimatic Extremes for Crop Cultivation and Diversification J. of IWRS 28 (4): pp. 34-42, 2008. 
[5] Jones, J.W., Hoogenboom, G., Porter, C.H., Boote, K.J., Batchelor, W.D., Hunt, L.A., Wilkens, P.W., Singh, U., Gijsman, A.J., Ritchie, J.T., The DSSAT cropping system model. European Journal of Agronomy. 18, 235265, 2003.

[6] Tripathi S.K., Kharif 2010 Ki Varsha Ka Phasalon Par Prabhav: Haridwar Uttarakhand Anubhav, Paper presented at "Mausam aur Jalvayu ka Krishi par Prabhav” Rashtriya Hindi Sangosthi held at Ministry of Earth Sciences, New Delhi on Dec. 10, 2010.

[7] Tripathi S.K. and G. Pranuthi,, Annual Progress Report of the project on "Forecasting Agriculture Output using Space, Agrometeorological and Land based observation (FASAL). Submitted to India Meteorology Department, Govt. of India New Delhi. pp. 27, 2012.

[8] Tripathi S.K., Concerns in Rainfall Pattern of South West Uttarakhand presented at Annual Meeting of India Meteorological Society held at IMD Kolkata, May 18-19, 2010.

[9] Sharma R.S. and S.K. Tripathi, Validation of Decision Support System for Agro Technology Transfer (DSSAT) on the Grain Yield of Rice cv IR64. Journal of Indian Water Resources Society 22 (3): 131-136, 2002.

[10] Hendrick, W.A. and J.C. Scholl,. Technique in measuring joint relationship - The joint effects of temperature and precipitation on crop yield. N. Carolina Agric. Exp. Sta. Tech. Bull., 74.1943.

[11] Agrawal, R. and R.C. Mehta, Weather Based Forecasting of Crop Yields, Pests and Diseases. Journal of the Indian Society of Agricultural Statistics, 61(2), 255-263, 2007. 